\title{
The ratio of calprotectin to total protein as a diagnostic marker for spontaneous bacterial peritonitis in patients with liver cirrhosis and ascites
}

\author{
Mansour N. Mohammed, Wesam A. Ibrahim, Mohammed M. Salama, \\ Amr A. El-Sayed Abd EI Kader \\ Department of Internal Medicine, Faculty of Medicine, Ain Shams University
}

Corresponding author: Amr Ahmed El-Sayed Abd El Kader,email:amrabdelkader90@gmail.com,mobile:01067199066.

\begin{abstract}
Background: Spontaneous bacterial peritonitis (SBP) is a potentially fatal condition, characterized by infection of ascitic fluid in absence of any intraabdominal surgically treatable source of infection.Diagnosis of SBP is based on a differential ascites leucocytic count. Aim of the Work: to assess the role of ascitic fluid calprotectin in diagnosis of SBP. Patients and Methods: A cross sectional study was conducted on 60 patients with decompensated liver disease were selected. They were divided into: 1) Non SBP Group: included 30 patients with cirrhotic ascites without clinical or laboratory evidence of spontaneous bacterial peritonitis. 2) SBP Group: included 30 patients with cirrhotic ascites and spontaneous bacterial peritonitis. Results:. Ascitic fluid calprotectin level and the ratio of calprotectin to total protein was statistically significant higher in SBP group than non SBP group. There was a significant decrease in total protein and albumin in ascitic fluid in SBP group compared to non SBP group .A significant positive correlation was detected between ascitic fluid calprotectin and ascitic fluid TLC and PNLs among SBP group, A significant positive correlation between the ratio of calprotectin to total protein and ascitic fluid TLC and PNLs among SBP group. Asitic fluid calprotectin at cut-off value $96 \mathrm{ng} / \mathrm{ml}$, had a sensitivity $86.67 \%$ and a specificity $76.67 \%$ in diagnosis of SBP with positive predictive value $85.2 \%$ and negative predictive value $78.8 \%$. - The ratio of calprotectin to total protein at cutoff value 9.6, had a sensitivity $96.67 \%$ and a specificity $90 \%$ in diagnosis of SBP with positive predictive value $96.4 \%$ and negative predictive value $90.6 \%$. Conclusion: The ratio of calprotectin to total protein had high sensitivity and specificity in diagnosis of SBP and better than calprotectin alone. The ratio of calprotectin to total protein could be a useful diagnostic test for SBP.
\end{abstract}

Key words: calprotectin, total protein, spontaneous bacterial peritonitis, cirrhosis, ascites

\section{Introduction}

Spontaneous bacterial peritonitis (SBP) is a distinct form of infectious peritonitis occurring in patients with advanced liver cirrhosis and ascites ${ }^{(\mathbf{1})}$.

SBP is associated with a high one year mortality after the first episode of about $30 \%$ (2). While SBP has a low incidence in outpatients (3), approximately $50 \%$ of SBP episodes in hospitalized patients are diagnosed at the time of admission ${ }^{(4)}$.
Symptoms of SBP include fever, chills, nausea, vomiting, abdominal pain and general malaise. Patients may complain of worsening of ascites ${ }^{\mathbf{5})}$.

Thirteen percent of patients have no symtoms and signs. Clinical diagnosis and systemic laboratory parameters are unreliable for diagnosis of SBP ${ }^{(6)}$.

According to international guidelines, diagnosis of SBP is based on a polymorphonuclear $(\mathrm{PMN})$ cell count of $>250 / \mu \mathrm{L}$ in the ascites in the absence of a surgically treatable intra-abdominal infection. However, a 
differential cell count is not readily available in all clinical settings. Nevertheless, a delay in establishing the diagnosis is associated with a poor prognosis ${ }^{(7)}$.

Attempts to establish alternative diagnostic tests are of limited success. In addition, no test provides prognostic information .A urinary test strip that detect leukocytes by their esterase activity performed well with a sensitivity of $100 \%$ and a specificity of $58 \%$.A drawback is that this test cannot be applied to bloody or chylous ascites samples, so that $16 \%$ of the tests could not be interpreted. First results of a urinary test strip were promising but have to be confirmed ${ }^{(8)}$.

An alternative approach is to detect proteins secreted by inflammatory cells into ascites. Lactoferrin, which is produced mainly by neutrophilic granulocytes, showed good test results ${ }^{(9)}$, but has not been introduced into clinical practice due to the lack of commercially available diagnostic test kits. Recently, a study evaluated calprotectin levels in ascites due to different etiologies of liver cirrhosis and found a strong correlation to ascites polymorphonuclear (PMN) number ${ }^{(10)}$.

Calprotectin is an acute phase inflammatory reaction protein originating mainly from polymorphonuclear (PMN) which exerts regulatory, antimicrobial and antiproliferative functions ${ }^{(\mathbf{1 1})}$.

Fecal calprotectin has been established as diagnostic tool in inflammatory bowel disease.Calprotectin can be measured also in bloody and chylous ascites, so that all samples could be analyzed ${ }^{(\mathbf{1 2})}$.

The ascitic fluid total protein concentration is lower in "spontaneously" infected ascitic fluid compared to sterile fluid obtained from different patients ${ }^{(13)}$.

\section{Aim of the work}

Assessment of ratio of calprotectin to total protein in ascites as an alternative diagnostic marker of SBP.

\section{Patients and methods}

This Cross sectional study was conducted at Gastroenterology and Hepatology Unit, Department of Internal Medicine, Ain Shams University Hospital and Ahmed Maher Educational Hospital. The study included a total number of 60 patients with liver cirrhosis and ascites were included in this study and were divided into two main groups:

1) Non-SBP Group: include 30 patients with liver cirrhosis and ascites without clinical or laboratory evidence of spontaneous bacterial peritonitis.

2) SBP Group: include 30 patients with liver cirrhosis and ascites and spontaneous bacterial peritonitis.

Diagnosis of SBP is based on a polymorphonuclear (PMN) cell count of $>250 / \mu \mathrm{L}$ in the ascites in the absence of a surgically treatable intra-abdominal infection (Arroyo et al., 2000).

Inclusion Criteria: Ascitic patients with clinical, laboratory, ultrasongraphic findings of liver cirrhosis were included.

Exclusion Criteria Patients have ascites due to causes other than liver cirrhosis, recent abdominal surgery ( $<3$ months), abdominal malignancy (HCC, Colorectal carcinoma, Gastric carcinoma, Pancreatic carcinoma, Cholangio carcinoma)., intaraabdominal infection e.g. abscess, appendicitis, cholecystitis, and pancreatitis

Ethical Considerations: Patients were informed about the research, freedom of choice to participate in the research or not was given to patients.

\section{Methods}

All patients were subjected to the following: 1. Full history taking: 2.Clinical examination: - Signs of chronic liver disease - Signs of SBP 3. Laboratory investigations: - Complete blood count, Liver function tests: (Serum albumin,liver enzymes, Bilirubin and INR). - Kidney function tests (urea and creatinine). 4. Calculation of Child's Pugh score 5. Abdominal ultra sonography 6. Diagnostic abdominal paracentesis: It was done for: i- 
Patients with cirrhosis and ascites at admission. ii- Patients who develop symptoms or signs of SBP during hospitalization .

Ascitic fluid analysis: $15 \mathrm{ml}$ of the ascitic fluid were aspirated from each patient and divided as follow: (I) $5 \mathrm{ml}$ for physical examination for: a) Color. b) Turbidity (II) $5 \mathrm{ml}$ for biochemical tests including: a) Total protein content. b) Albumin. c) Calprotectin (ELISA). (III) $5 \mathrm{ml}$ for WBCs (total and differential). Calprotectin was measured in $1 \mathrm{~mL}$ ascitic fluid by Enzyme-Linked Immuno Sorbent Assay (ELISA) to assay the level of Human Calprotectin in samples.

\section{Statical analysis}

Data were collected, coded, revised and entered to the Statistical Package for Social Science (IBM SPSS) version 20. The data were presented as number and percentages for the qualitative data, mean, standard deviations and ranges for the quantitative data with parametric distribution and median with inter quartile range (IQR) for the quantitative data with non parametric distribution. Chi-square test was used in the comparison between two groups with qualitative data and Fisher exact test was used instead of the Chi-square test when the expected count in any cell found less than Independent t-test was used in the comparison between two groups with quantitative data and parametric distribution and Mann-Whitney test was used in the comparison between two groups with quantitative data and non parametric distribution. Spearman correlation coefficients were used to assess the significant relation between two quantitative parameters in the same group. Receiver Operating Characteristic curve (ROC) was used to assess the best cut off point between two groups with its sensitivity, specificity, positive predictive value (PPV), negative predictive value (NPV) and area under the curve (AUC).The confidence interval was set to $95 \%$ and the margin of error accepted was set to $5 \%$. So, the p-value was considered significant as the following: $\mathrm{P}>0.05$ : Non significant, $\mathrm{P}<$ 0.05: Significant.

\section{Results}

Table (1): Comparison between SBP group \& Non SBP group as regards sex

\begin{tabular}{|c|c|c|c|c|c|c|c|}
\hline & & \multicolumn{2}{|c|}{$\begin{array}{l}\text { SBP group } \\
(\text { No.=30) }\end{array}$} & \multicolumn{2}{|c|}{$\begin{array}{l}\text { Non SBP group } \\
(\text { No.=30) }\end{array}$} & \multicolumn{2}{|c|}{ CHI square test } \\
\hline & & No. & $\%$ & No. & $\%$ & $\mathrm{X}^{2}$ & P value \\
\hline \multirow{2}{*}{ Sex } & Female & 13 & $43.3 \%$ & 17 & $56.7 \%$ & \multirow{2}{*}{1.067} & \multirow{2}{*}{0.302} \\
\hline & Male & 17 & $56.7 \%$ & 13 & $43.3 \%$ & & \\
\hline
\end{tabular}

This table shows that there was no statistical significant difference between studied groups as regards sex .

Table (2): Comparison between SBP group \& Non SBP group as regards age

\begin{tabular}{|c|c|c|c|c|c|}
\hline & & \multirow{2}{*}{$\begin{array}{l}\text { SBP group } \\
(\text { No.=30) }\end{array}$} & \multirow{2}{*}{$\begin{array}{l}\text { Non SBP group } \\
(\text { No.=30) }\end{array}$} & \multicolumn{2}{|c|}{ Independent $\mathrm{t}$ test } \\
\hline & & & & $\mathbf{T}$ & P value \\
\hline \multirow{2}{*}{ Age } & Mean & 56.83 & 55.83 & \multirow{2}{*}{0.491} & \multirow{2}{*}{0.625} \\
\hline & Standard deviation & 7.64 & 8.12 & & \\
\hline
\end{tabular}

This table shows that there was no statistical significant difference between studied groups as regards age .

Table (3): Comparison between SBP group \& Non SBP group as regards laboratory investigations

\begin{tabular}{|c|c|c|c|c|c|c|c|}
\hline & \multirow[t]{2}{*}{ Normal value } & \multicolumn{2}{|c|}{$\begin{array}{l}\text { SBP group } \\
(\text { No.=30) }\end{array}$} & \multicolumn{2}{|c|}{$\begin{array}{l}\text { Non SBP group } \\
(\text { No.=30) }\end{array}$} & \multicolumn{2}{|c|}{ Independent $t$ test } \\
\hline & & Mean & SD & Mean & SD & $\mathbf{T}$ & P value \\
\hline $\mathrm{HB}$ & $(12-15)$ & 8.81 & 1.05 & 9.51 & 1.23 & -2.385 & 0.020 \\
\hline TLC & $(4-11)$ & 11.63 & 3.53 & 5.24 & 1.49 & 9.137 & 0.001 \\
\hline PLT & $(150-400)$ & 86.90 & 20.73 & 109.13 & 19.53 & -4.276 & 0.001 \\
\hline ALT & $(10-40)$ & 72.70 & 14.08 & 65.43 & 15.28 & 0.977 & 0.271 \\
\hline AST & $(10-40)$ & 71.60 & 16.01 & 70.30 & 15.79 & 0.317 & 0.753 \\
\hline Total BIL & $(0.3-1.2)$ & 3.13 & 2.58 & 2.16 & 0.70 & 1.977 & 0.053 \\
\hline DIRECT BIL & (up to 0.2) & 1.91 & 2.90 & 1.40 & 0.47 & 0.958 & 0.342 \\
\hline
\end{tabular}




\begin{tabular}{|l|l|l|l|l|l|l|}
\hline ALBUMIN & $(3.5-5.3)$ & 2.61 & 0.30 & 2.94 & 0.16 & -5.408 \\
\hline INR & $(1)$ & 1.67 & 0.17 & 1.56 & 0.21 & 2.235 \\
\hline UREA & $(20-40)$ & 64.43 & 27.69 & 66.27 & 27.93 & -0.255 \\
\hline CREATININ & $(0.4-1.3)$ & 1.84 & 0.53 & 1.44 & 0.029 & 0.32 \\
\hline
\end{tabular}

This table shows that there was statistically significant increase in SBP group in comparison to non SBP group as regards TLC, INR and creatinin but decrease in SBP group in comparison to non SBP group with HB, PLT and albumin.

Table (4): Comparison between SBP group \& Non SBP group as regards ascitic fluid analysis

\begin{tabular}{|l|l|l|l|l|l|l|}
\hline \multirow{2}{*}{} & \multicolumn{2}{l}{$\begin{array}{l}\text { SBP group } \\
\text { (No.=30) }\end{array}$} & \multicolumn{2}{l|}{$\begin{array}{l}\text { Non SBP group } \\
\text { (No.=30) }\end{array}$} & \multicolumn{2}{l|}{ Independent t test } \\
\cline { 2 - 8 } & Mean & SD & Mean & SD & T & P value \\
\hline Total protein $(\mathrm{g} / \mathrm{l})$ & 9.2 & 1.6 & 17.4 & 2.1 & -17.162 & 0.001 \\
\hline ALBUMIN(g/dl) & 0.52 & 0.10 & 0.84 & 0.13 & -10.999 & 0.001 \\
\hline SAAG & 2.09 & 0.33 & 2.10 & 0.20 & -0.085 & 0.932 \\
\hline TLC & 955.33 & 222.30 & 303.33 & 186.59 & 12.304 & 0.001 \\
\hline PNLS & 406.83 & 120.88 & 78.87 & 39.33 & 14.131 & 0.001 \\
\hline
\end{tabular}

This table shows that there was statistically significant increase in SBP group in comparison to non SBP group as regards TLC and PNLs but decrease in SBP group in comparison to non SBP group with total protein and albumin.

Table (5): Comparison between SBP group \& Non SBP group as regards calprotectin and calprotectin to total protein ratio

\begin{tabular}{|l|l|l|l|l|l|l|}
\hline \multirow{2}{*}{} & \multicolumn{2}{|l|}{$\begin{array}{l}\text { SBP group } \\
\text { (No.=30) }\end{array}$} & \multicolumn{2}{l|}{$\begin{array}{l}\text { Non SBP group } \\
\text { (No.=30) }\end{array}$} & \multicolumn{2}{l|}{$\begin{array}{l}\text { Independent } \\
\text { t test }\end{array}$} \\
\cline { 2 - 7 } & Mean & SD & Mean & SD & t & P value \\
\hline Calprotectin (ng/ml) & 915.67 & 1232.20 & 102.23 & 119.97 & 3.599 & 0.001 \\
\hline Calprotectin to total protein ratio & 116.98 & 145.94 & 5.88 & 8.10 & 4.164 & 0.001 \\
\hline
\end{tabular}

This table shows that there was statistically significant increase in SBP group in comparison to non SBP group as regards calprotectin and ratio of calprotectin to total protein

Table (6): Comparison between SBP group \&Non SBP group as regards ultrasound

\begin{tabular}{|c|c|c|c|c|c|c|c|}
\hline & & \multicolumn{2}{|c|}{$\begin{array}{l}\text { SBP group } \\
(\text { No.=30) }\end{array}$} & \multicolumn{2}{|c|}{$\begin{array}{l}\text { Non SBP group } \\
(\text { No.=30) }\end{array}$} & \multicolumn{2}{|c|}{ Chi square test } \\
\hline & & No. & $\%$ & No. & $\%$ & $\mathbf{X}^{2}$ & P value \\
\hline$\overline{\mathrm{LC}}$ & $+\mathrm{ve}$ & 30 & $100.0 \%$ & 30 & $100.0 \%$ & NA & NA \\
\hline HFL & -ve & 30 & $100.0 \%$ & 30 & $100.0 \%$ & NA & NA \\
\hline \multirow{2}{*}{ Ascites } & moderate & 14 & $46.7 \%$ & 15 & $50.0 \%$ & \multirow{2}{*}{0.067} & \multirow{2}{*}{0.796} \\
\hline & severe & 16 & $53.3 \%$ & 15 & $50.0 \%$ & & \\
\hline
\end{tabular}

There is no patients with HFL to exclude any cause of ascites other than live cirrhosis.

Table (7): Comparison between SBP group \& Non SBP group as regards child score

\begin{tabular}{|c|c|c|c|c|c|c|c|}
\hline & & \multicolumn{2}{|c|}{$\begin{array}{l}\text { SBP group } \\
(\text { No.=30) }\end{array}$} & \multicolumn{2}{|c|}{$\begin{array}{l}\text { Non SBP group } \\
(\text { No.=30) }\end{array}$} & \multicolumn{2}{|c|}{ CHI square test } \\
\hline & & No. & $\%$ & No. & $\%$ & $\mathrm{X}^{2}$ & P value \\
\hline \multirow{2}{*}{ Child score } & B & 10 & $33.3 \%$ & 23 & $76.6 \%$ & \multirow[b]{2}{*}{8.378} & \multirow[b]{2}{*}{0.212} \\
\hline & $\mathrm{C}$ & 20 & $66.7 \%$ & 7 & $23.4 \%$ & & \\
\hline
\end{tabular}

The majority of SBP patients were child -paugh class C $(66.7 \%)$ but without significant difference in between SBP and non SBP groups.

Table (8): Correlation between calprotectin and calprotectin to total protein ration as regards all parameters in SBP group

\begin{tabular}{|c|c|c|c|c|}
\hline & \multicolumn{2}{|c|}{ Calprotectin (ng/ml) } & \multicolumn{2}{|c|}{ Calprotectin to total protein ratio } \\
\hline & $\mathbf{r}$ & P value & $\mathbf{R}$ & P value \\
\hline
\end{tabular}




\begin{tabular}{|c|c|c|c|c|}
\hline Age & 0.043 & 0.820 & -0.026 & 0.891 \\
\hline \multicolumn{5}{|c|}{ Laboratory investigations } \\
\hline $\mathrm{HB}$ & 0.246 & 0.190 & 0.200 & 0.290 \\
\hline TLC & 0.178 & 0.346 & 0.067 & 0.725 \\
\hline $\begin{array}{l}\text { PLT } \\
\end{array}$ & -0.110 & 0.563 & -0.144 & 0.449 \\
\hline ALT & -0.313 & 0.092 & -0.243 & 0.196 \\
\hline AST & -0.196 & 0.299 & -0.085 & 0.654 \\
\hline T.BIL & -0.227 & 0.228 & -0.286 & 0.125 \\
\hline DIRECT BIL & -0.082 & 0.665 & -0.129 & 0.496 \\
\hline ALBUMIN & 0.051 & 0.789 & 0.083 & 0.664 \\
\hline INR & -0.118 & 0.535 & -0.086 & 0.651 \\
\hline UREA & 0.051 & 0.789 & 0.086 & 0.651 \\
\hline CREATININ & -0.007 & 0.969 & 0.012 & 0.949 \\
\hline \multicolumn{5}{|l|}{ Fluid analysis } \\
\hline Total protein $(\mathrm{g} / \mathrm{l})$ & 0.301 & 0.106 & 0.044 & 0.819 \\
\hline ALBUMIN & -0.401 & 0.028 & -0.364 & 0.048 \\
\hline SAAG & 0.089 & 0.640 & 0.110 & 0.563 \\
\hline TLC & 0.439 & 0.015 & 0.462 & 0.010 \\
\hline PNLS & 0.351 & 0.049 & 0.365 & 0.047 \\
\hline
\end{tabular}

This table shows that calprotectin has negative correlation with albumin in ascitic fluid and positive correlation with TLC and PNLs in ascitic fluid but calprotectin to total protein ratio has negative correlation with albumin in ascitic fluid while has positive correlation with TLC and PNLs in ascitic fluid.

Table (9): Cutoff point, sensitivity and specificity of calprotectin between SBP group and non SBP group

\begin{tabular}{|l|l|l|l|l|l|}
\hline Cutoff point & AUC & Sensitivity & Specificity & NPV & PPV \\
\hline$>96$ & 0.877 & 86.67 & 76.67 & 85.2 & 78.8 \\
\hline
\end{tabular}

This table shows that in calprotectin: The cutoff point of calprotectin $>96$, Its sensitivity is $86.67 \%$, Its specificity is $76.67 \%$, The positive predictive value is $85.2 \%$ and the negative predictive value is $78.8 \%$

Table (10): Cutoff point, sensitivity and specificity of calprotectin to total protein ratio between SBP group and non SBP group

\begin{tabular}{|l|l|l|l|l|l|}
\hline Cutoff point & AUC & Sensitivity & Specificity & NPV & PPV \\
\hline$>9.6$ & 0.961 & 96.67 & 90.00 & 96.4 & 90.6 \\
\hline
\end{tabular}

This table shows that in calprotectin to total protein ratio:, The cutoff point of calprotectin to total protein ratio $>9.6$, Its sensitivity is $96.67 \%$, Its specificity is $90 \%$, The positive predictive value is $96.4 \%$, The negative predictive value is $90.6 \%$

\section{Discussion}

Ascites is one of the most common complications of patients with cirrhosis and its development carries a relatively poor prognosis but the overall course depends on the degree of reversibility of the underlying liver disease and the response to therapy ${ }^{(14)}$.

Spontaneous bacterial peritonitis is defined as an infection of a previously sterile ascitic fluid in the absence of any evident intraabdominal surgical source of infection ${ }^{(15)}$.
Calprotectin, a calcium and zinc-binding protein that belong to the $\mathrm{S} 100$ protein family. It is detected almost exclusively in neutrophils, and its presence in body fluids is proportional to the influx of neutrophils. Calprotectin is primarily expressed in neutrophils and macrophages, while it is not usually present in lymphocytes. Calprotectin constitutes up to $60 \%$ of soluble protein content in the cytosol of neutrophil granulocytes ${ }^{(\mathbf{1 6})}$. 
A high level of calprotectin reportedly exists in extracellular fluid during various inflammatory conditions, such as SBP ${ }^{(17)}$.

The aim of this study is assessment of the role of ratio of calprotectin to total protein in ascites for diagnosis of SBP and to identify a cut - off level of this ratio.

In order to achieve this goal, we selected 60 patients with liver cirrhosis and ascites, 30 patients without SBP, and other 30 patients with SBP admitted in Ahmed Maher Educational Hospital during study period.

In this study, patients with SBP was 56.7 $\%$ males and $43.3 \%$ females with no statically significant difference, mean age of patients with SBP is $56.83 \pm 7.64$ and mean age of patients without SBP is $55.83 \pm 8.12$ without statistically significant difference .

Regarding of the parameters of laboratory investigations in this study, SBP group showed statistically significant decrease in hemoglobin level when compared to non-SBP groups $(\mathrm{p}=$ 0.020) .

Similar result was obtained by Wojtacha A et al., (18) who reported decreased level of haemoglobin in SBP patients, this can be explained that patients with more severe liver disease have lesser HB and they are more likely to have SBP.

On the other hand, Coşkun et al., (19) stated that no significant difference between SBP and non-SBP groups as regard hemoglobin level.

Regarding total leucocytic count, there was statistically significant increase in serum total leucocytic count when compared to nonSBP $\operatorname{groups}(\mathrm{p}=0.001)$.Similar result was obtained by Rodríguez-Ramos et al, ${ }^{(20)}$ who

detected leucocytosis in their SBP cases with significant difference when compared to non SBP cases.

These results differ from some published studies as Cholongitas et al., (21) who stated that there was leucocytosis in SBP patients but with no statistically significant difference between SBP and non SBP patients $(\mathrm{p}=0.11)$.
In this study there was reduced platelets count in SBP and non SBP patients but it was much lower in SBP group (86.9 \pm 20.73 versus $109.13 \pm 19.35 \times 1000 \mathrm{cell} / \mathrm{cmm})$. These results are consistent with those of Lata et al., ${ }^{(22)}$ who reported statically significant lower platelet counts in a group of SBP patients and supposed that the reduction of the platelet count in patients with spontaneous bacterial peritonitis indicates the influence of portal hypertension in the aetiology of the disease.

As regard liver enzymes our result showed that there were no statistically significant differences between SBP and non SBP groups. This is in accordance with Salama et al., ${ }^{(23)}$.

On the contrary, Coral et al., (24) stated that the level of serum ALT, AST was significantly higher in cirrhotic patients with SBP group than non-SBP group.

Regarding serum bilirubin, We noted higher serum bilirubin level in SBP compared to non SBP groups with no statistically significant differences in between, this match results of Kim et al., (25), Thiele et al., (26). These results differ from results of Umgelter et al., (27) who stated that the level of serum bilirubin was significantly higher in cirrhotic patients with SBP group than non-SBP group.

In the current study, serum albumin level in SBP groups was statistically significantly lower than in non -SBP group. This result goes in agreement with Ruiz et al., ${ }^{(28)}$.

Regarding international normalization ratio (INR) it was it was significantly higher in SBP patients more than non SBP patients.

Similar result concluded by Oladimeji et al., ${ }^{(29)}$ who reported that, INR was significantly higher in those patients with SBP compared with those without SBP.

In this study, the level of serum creatinine was significantly increased in patients with SBP when compared to non SBP patients and this result goes in agreement with Angeloni et al., ${ }^{(30)}$, who concluded that the hospital mortality in SBP is high due to renal impairment which is common in SBP patients 
either due to prerenal or hepatorenal causes and also reinforced by Tsung et al., ${ }^{(31)}$ who stated that renal dysfunction occurs in patients with SBP and it is independent predictor of mortality.

On the other hand, Zalam et al. ${ }^{(32)}$ stated that there was no statistical significant difference comparing SBP \& non SBP patients as regards kidney function.

Chemical analysis of ascitic fluid showed that total protein concentration was significantly lower in SBP than non SBP group. These results were in line with Paul K et al., ${ }^{(33)}$ who reported that opsonic activity of ascitic fluid has been shown to correlate closely with the fluid's protein concentration; fluids with $<1.0$ $\mathrm{g} / \mathrm{dl}$ of protein have been reported to have diminished opsonic activity and therefore high susceptibility to SBP.

On the other hand this result disagree with Abdel-Razik A et al. ${ }^{(34)}$ who found that patients with SBP has an increase in ascitic fluid total protein which has an important role in the inflammatory process in SBP.

The present study revealed that the mean value of SAAG was $>1.1 \mathrm{~g} / \mathrm{dl}$ in both $\mathrm{SBP}$ and non-SBP groups but without significant difference, which confirms that etiology of ascites was portal hypertension in these patients. This finding is in concordance with Agarwal et al. ${ }^{(35)}$ study which suggested that SAAG levels are $>1.1 \mathrm{~g} / \mathrm{dl}$ in all ascites due to portal hypertension irrespective of infection.

This can be explained by the results of current study that reported decreased level of both serum albumin and ascitic albumin in SBP patients .

Chemical analysis of ascitic fluid showed that, statistically significantly higher levels of TLC, PMN count in SBP group compared to non SBP group, these results

were in line with Yildirim et al., ${ }^{(36)}$ who reported higher ascitic TLC in SBP more than non SBP patients. Also Jansen ${ }^{(37)}$ stated that, although ascitic TLC count increases in SBP cases, it suffers from low specificity because a large proportion of patients with sterile ascites have increased white blood cell count. Also diuretic therapy has been shown to increase the TLC count but does not alter the PMN count.

In the present work, we found that the majority of SBP patients were child -paugh class $\mathrm{C}(66.7 \%)$ but without significant difference in between SBP and non SBP groups $(p=0.212)$.This result matched with that reported by Cirera et al., ${ }^{(38)}$ who conducted a study on 136 SBP patients and reported that about $70 \%$ of patients who developed SBP had Child class $\mathrm{C}$.

In this study, that ascitic fluid calprotectin was detected in both groups. There was statistically significant increase in ascitic fluid calprotectin in SBP group when compared with non SBP group. This finding is in concordance with Burri et al. ${ }^{(10)}$.

Also Abdel-Razik A et al. ${ }^{(34)}$ show that serum procalcitonin and ascitic calprotectin were significantly higher in SBP patients than in non-SBP patients.

This study revealed that ascitic fluid calprotectin to total protein ratio was statistically significant higher in SBP patients than non SBP patients $(116.98 \pm 145.94 \& 5.88$ $\pm 8.1)$ respectively $(\mathrm{p}=0.001)$.

A result which is consistent with those demonstrated in the study of Lutz et al. ${ }^{(39)}$.

Further analysis of results revealed statistically significant positive correlation between ascitic fluid calprotectin and ascitic fluid TLC and PNLs among SBP group.Similar result were obtained by Soyfoo et al., ${ }^{(16)}$ who concluded that calprotectin is detected almost exclusively in neutrophils, and its presence in body fluids is proportional to the influx of neutrophils. And goes also in agreement with Burri et al., (10) who say that ascitic fluid calprotectin helpful in detection of neutrophil count .

While in current study there was a significant negative correlation between ascitic calprotectin and ascitic fluid albumin among SBP group $(p=0.003)$, this result goes in agreement with Gupta et al. ${ }^{(40)}$ who explained that in cirrhotic patient there is a decrease in 
synthetic function of the liver which aggravated by sepsis the net result is decrease serum albumin which by its role decrease the diffused albumin to ascitic fluid.

This study reavealed statistically significant positive correlation between ascitic fluid calprotectin to total protein ratio and ascitic fluid TLC and PMNLs among SBP group and significant negative correlation between ascitic calprotectin to total protein ratio and ascitic fluid albumin among SBP group.

The present study demonstrated that, ascitic fluid calprotectin at a cutoff value of 96 $\mathrm{ng} / \mathrm{ml}$, had $86.67 \%$ sensitivity and $76.67 \%$ specificity with positive predictive value 78.8 $\%$ and negative predictive value $85.2 \%$ in diagnosis of SBP, AUC was 0.877, while cut off value of calprotectin to total protein ratio was 9.6, had $96.67 \%$ sensitivity and 90\% specificity with positive predictive value 90.6 $\%$ and negative predictive value $96.4 \%$, AUC was 0.961 .

Lutz et al. (39) show that optimal cutoff value of calprotectin above $36 \mathrm{ng} / \mathrm{ml}$, had $90 \%$ sensitivity and $51 \%$ specificity, AUC was 0.85 , while cut off value of calprotectin to total protein ratio was 5.24 , had $93 \%$ sensitivity and $81 \%$ specificity, AUC was 0.93 .

The noticeable difference between cutoff value of calprotectin and the ratio of calprotectin to total protein between this study and Lutz et al. (39) study may be due to low number of patients in both studies.

Many previous studies evaluated the diagnostic utility of measuring ascitic fluid calprotectin to diagnose SBP but this study added that the ratio of calprotectin to total protein can be used as an alternative diagnostic marker with better sensitivity and specificity than calprotectin alone.

Finally, larger studies are needed to evaluate this test in different clinical settings and to establish a reliable cut-off value for ascitic calprotectin to total protein ratio.

\section{Conclusion}

-The ratio of calprotectin to total protein had high sensitivity and specificity in diagnosis of SBP and better than calprotectin alone .

- The ratio of calprotectin to total protein could be a useful diagnostic test for SBP.

\section{References}

1. Wiest R, Krag A and Gerbes A (2012): Spontaneous bacterial peritonitis: recent guidelines and beyond. Gut; 61: 297-310.

2. Ariza $X$, Castellote J, Lora-Tamayo J, Girbau A, Salord $S$ and Rota $R$, et al.(2012): Risk factors for resistance to ceftriaxone and its impact on mortality in community, healthcare and nosocomial spontaneous bacterial peritonitis. $\mathbf{J}$ Hepatol;56:825-32.

3. Evans LT, Kim WR, Poterucha JJ, et al., (2003): Spontaneous bacterial peritonitis in asymptomatic outpatients with cirrhotic ascites. J Hepatol; 37(4): 897-901.

4. Rimola A, Garcia-Tsao G, Navasa $M$, Piddock LJ, Planas $R$ and Bernard B, et al. (2000): Diagnosis, treatment and prophylaxis of spontaneous bacterial peritonitis: a consensus document. J Hepatol;32:142-53

5. Lata J, Stiburek $O$ and Kopacova $M$ (2009):"Spontaneous bacterial peritonitis: a severe complication of liver cirrhosis". World J. Gastroenterol; 15 (44): 5505-10.

6. Su D, Zhuo C, Guan J, Liao K, Cheng W and Cheng H, et al. (2012): Value of serum procalcitonin levels in predicting spontaneous bacterial peritonitis. Hepatogastroenterology; 60:641-6.

7. Kim JJ, Tsukamoto MM, Mathur AK, Ghomri YM, Hou LA and Sheibani S, et al (2014): Delayed paracentesis is associated with increased in-hospital mortality in patients with spontaneous bacterial peritonitis. Am J Gastroenterol; 109:143642.

8. Mendler MH, Agarwal A, Trimzi M, Madrigal E, Tsushima $M$ and Joo E, et al. (2010): A new highly sensitive point of care 
screen for spontaneous bacterial peritonitis using the leukocyte esterase method. J Hepatol;53:477-83.

9. Parsi MA, Saadeh SN, Zein NN, et al., (2008): Ascitic fluid lactoferrin for diagnosis of spontaneous bacterial peritonitis. Gastroenterology; 135(3):803-7.

10. Burri E, Schulte F, Muser J, Meier R and Beglinger $C$ (2013): Measurement of calprotectin in ascitic fluid to identify elevated polymorphonuclear cell count. World J Gastroenterol; 19:2028-36.

11. Yui S, Nakatani $Y$ and Mikami $M$. Calprotectin(2003): (S100A8/S100A9), an inflammatory protein complex from neutrophils with a broad apoptosis-inducing activity. Biol Pharm Bull;26:753-60

12. Sherwood RA. (2012): Faecal markers of gastrointestinal inflammation. J ClinPathol;65:981-5.

13. Llach J, Rimola A, Navasa $M$, et al (1992):Incidence and predictive factors of first episode of spontaneous bacterial peritonitis in cirrhosis with ascites: relevance of ascitic fluid protein concentration. Hepatology.;16:724-7.

14. Friedman $S$ and Schiano $T$ (2010): Cirrhosis and its sequelae. In:Goldman L, Ausiello D, eds. Cecil Textbook of Medicine. 22nded. Philadelphia, Pa.: Saunders:936-44.

15. Soriano G, Castellote J, Alvarez C, et al., (2010): Spontaneous \&secondary bacterial peritonitis in cirrhosis: a retrospective study of clinical and analytical characteristics, diagnosis and management $\mathrm{J}$. Hepatol; 12:52:39.

16. Soyfoo MS, Roth J, Vogl T, et al.,(2009): Phagocyte specific S100A8/A9 (calprotectin) protein levels during disease exacerbations and infections. Arthritis Res Ther.; 36: 2190- 2194.

17. Brophy $M$, Elizabeth $N$ and Clark $H$ (2015): "Manganese and Microbial Pathogenesis: Sequestration by the Mammalian Immune System and Utilization by Microorganisms". ACS Chemical Biology; 10(3):1012-27

18. Wojtacha A, Juszczyk J, Czarniak E and Samet A (2004): Spontaneous bacterial peritonitis in patients with decompensated liver cirrhosis based on bacteriological and biochemical results; 58(4):597-607.

19. Coșkun U, Ozenirler S, Sancak B, et al.,(2001): Serum and ascitic fluid hemoglobin levels in patients with cirrhosis. Clin Chim Acta; 306(1-2):127-32.

20. Rodríguez-Ramos C, Galan F, Díaz F, Elvira J, Martín-Herrera $L$ and GirónGonzález JA (2001): Expression of proinflammatory cytokines and their inhibitors during the course of spontaneous bacterial peritonitis. Dig Dis Sci; 46(8): 1668-1676.

21. Cholongitas E, Papatheodoridis GV, Manesis EK, Burroughs AK and Archimandritis AJ (2006): Spontaneous bacterial peritonitis in cirrhotic patients: Is prophylactic propranolol therapy beneficial? J. Gastroenterol and Hepatolgy; 21 (3):581587.

22. Lata J, Fejfar T, Krechler T, Musil T, Husova L, Senkyrik M, et al., (2003): Spontaneous bacterial peritonitis in the Czech Republic: prevalence and aetiology. Eur J Gastroenterol Hepatol.; 15 (7):739-43.

23. Salama MK, Sabry D, Al-Ghussein MAS, Ahmed R, AbdAllah S, Taha FM, et al., (2014):Molecular detection of monocyte chemotactic protein-1 polymorphism in spontaneous bacterial peritonitis patients. WorldJ Gastroenterol; 20(33): 11793-11799.

24. Coral G, Mattos A, Valiatti F, et al., (2002): Bacterial infections in cirrhotic patients. World J Gastroenterol; 20(39):14079-86.

25. Kim JK, Chon CY, Kim JH, Kim YJ, Cho JH, Bang SM, et al., (2007): Changes in serum and ascitic monocyte chemotactic Protein-1 (MCP-1) and IL-10 levels in cirrhotic patients with spontaneous bacterial peritonitis. J Interferon Cytokine Res.; 27(3):227-30. 
26. Thiele GB, Silva OM, Fayad L, Lazzarotto C, Ferreira Mdo A, Marconcini ML, et al., (2014): Clinical and laboratorial features of spontaneous bacterial peritonitis in southern Brazil. Sao Paulo Med. J.; 132(4):205-210.

27. Umgelter A, Reindl W, Miedaner $M$, Schmid RM and Huber W (2009): Failure of Current Antibiotic First-Line Regimens and Mortality in Hospitalized Patients with Spontaneous Bacterial Peritonitis. Infection; 37(1): 2-8.

28. Ruiz A, Urman J, Fernandez J, et al., (2003): Systemic renal and hepatic haemodynamic derangement in cirrhotic patients with spontaneous badcterial peritonitis. Hepatology; 38: 1210 - 18

29. Oladimeji AA, Temi AP, Adekunle AE, et al., (2013): Prevalence of spontaneous bacterial peritonitis in liver cirrhosis with ascites. Pan African Medical Journal; 15:128-36.

30. Angeloni S, Leboffe C, Parente A, et al., (2008): Efficacy of current guidelines for diagnosis and treatment of spontaneous bacterial. World J Gastroenterol;14: 27572762.

31. Tsung PC, Ryu SH, Cha IH, et al.,(2013): Predictive factors that influence the survival rates in liver cirrhosis patients with spontaneous bacterial peritonitis. J clinical and molecular hepatplogy; 19:131-139.

32. Zalam, S.; Elshazly, H.; Farag, M.; et al. (2010): Th role of serum and ascetic fluid TNF-Receptor 1 and C-Rractive protein (CRP) in patients with cirrhotic ascites. Scientific Medical Journal (cairo) (2010), 41,491-501.

33. Paul K, Kaur J and Kazal HL (2015): Study of the Incidence, Predictive Factors and Clinical Outcome of Spontaneous Bacterial Peritonitis in Patients of Cirrhosis with Ascites; 10.7860.

34. Abdel-Razik A, Mousa N, Elhammady D, et al.,(2016): Ascitic Fluid Calprotectin and Serum Procalcitonin as Accurate Diagnostic
Markers for Spontaneous Bacterial Peritonitis. Gut Liver; 10(4):624-31.

35. Agarwal MP, Choudhury BR, Banerjee BD, et al. (2008): Ascitic fluid examination for diagnosis of spontaneous bacterial peritonitisin cirrhotic ascites. Journal, Indian Academy of Clinical Medicine; 9 (1):29-32.

36. Yildirim B, Sari R, Isci N, et al.,(2005): Patients with spontaneous bacterial peritonitis, and malignant and cirrhotic ascites. J Natl Med Assoc; 97: 276-80.

37. Jansen PL (1997): Spontaneous bacterial peritonitis. Detection, treatment and prophylaxis in patients with liver cirrhosis. Neth J Med; 51(4): 123 - 128

38. Cirera I, Bauer TM, Navasa M, et al., (2001): Bacterial translocation of enteric organisms in patients with cirrhosis. $\mathbf{J}$ Hepatol; 34: 32-37.

39. Lutz $P$, Pfarr $K$, Nischalke HD and Krämer B (2015): The ratio of calprotectin to total protein as a diagnostic and prognostic marker for spontaneous bacterial peritonitis in patients with liver cirrhosis and ascites; 10.1515.

40. Gupta R, Misra SP, Dwivedi M, et al. (2007): Diagnosing ascites: value of ascitic fluid total protein, albumin, cholesterol, their ratios, serum-ascites albumin and cholesterol gradient. J Gastroenterol Hepatol;10(3): 295-99 